\title{
Orb Weavers, Neoscona crucifera (Lucas 1839) and Neoscona domiciliorun (Hentz) (Arachnidae: Araneae: Araneidae) $)^{1}$
}

G. B. Edwards ${ }^{2}$

\section{Introduction}

Neoscona crucifera (Lucas 1839) and $N$. domiciliorum (Hentz 1847) are common and conspicuous members of the moist woodland communities in much of Florida. These spiders are beneficial, consuming a variety of insects. Although typically nocturnal throughout most of their life spans, adult females can be found sitting head down in the hubs of their webs during daylight hours of the fall season. Bites from these spiders are not known to cause serious effects to humans.

\section{Distribution}

These spiders have a wide geographic range: $N$. crucifera is found from Lake Okeechobee in southern Florida north to New England, west to Minnesota, and southwest to Arizona and central Mexico, whereas $N$. domiciliorum occurs southeast of a line drawn from Massachusetts to Indiana southwest to Texas. In the more northern states, males may mature as early as late June and females in July (Berman and Levi
1971), but in Florida, adults usually are not apparent until late August.

\section{Systematics}

These two species have been confused with each other, mostly due to the interpretations by various authors of the descriptions by Walckenaer (1841) of two forms of Epeira benjamina from an unpublished manuscript of drawings of Georgia spiders made by John Abbot in 1792. Berman and Levi (1971), who reviewed the history of the controversy, decided to use the name $N$. hentzii (Keyserling 1864) in place of $N$. benjamina, since $N$. hentzii was the oldest name with adequate description and certain interpretation. They also designated a neotype for $N$. domiciliorum (Hentz). However, since then, N. hentzii was synonymized with $N$. crucifera (Grasshoff 1986).

\section{Diagnosis}

$N$. crucifera and $N$. domiciliorum are similar, but can be distinguished by several characters. Generally, $N$. crucifera is the larger and more common of the

1. This document is EENY-316 (originally published as DPI Entomology Circular 266), one of a series of Featured Creatures from the Entomology and Nematology Department, Florida Cooperative Extension Service, Institute of Food and Agricultural Sciences, University of Florida. Published: June 2003. This document is also available on Featured Creatures Website at http://creatures.ifas.ufl.edu. Please visit the EDIS Website at http://edis.ifas.ufl.edu. Additional information on these organisms, including many color photographs, is available at the Entomology and Nematology Department website at http://entnemdept.ifas.ufl.edu/.

2. G. B. Edwards, Florida Department of Agriculture and Consumer Services, Division of Plant Industry, Gainesville, FL.

The Institute of Food and Agricultural Sciences (IFAS) is an Equal Employment Opportunity - Affirmative Action Employer authorized to provide research, educational information and other services only to individuals and institutions that function without regard to race, creed, color, religion, age, disability, sex, sexual orientation, marital status, national origin, political opinions or affiliations. For information on obtaining other extension publications, contact your county Cooperative Extension Service office. Florida Cooperative Extension Service / Institute of Food and Agricultural Sciences / University of Florida / Larry R. Arrington, Interim Dean 


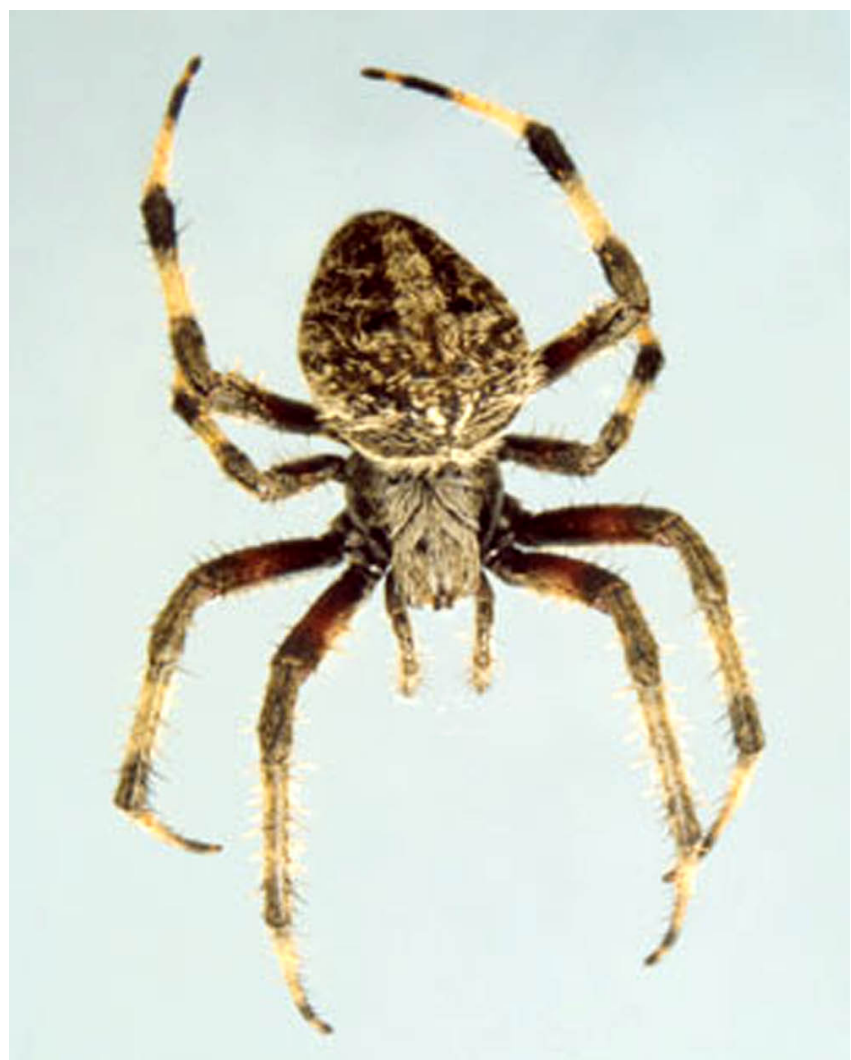

Figure 1. Dorsal view of female Neoscona crucifera (Lucas), an orb weaver. Credits: G.B. Edwards, FDACS-DPI

two species. It has more drab coloration, with females reddish-brown to brown, and males lighter brown with the sides of the carapace nearly black. Northern females are occasionally white. On the other hand, female $N$. domiciliorum have a bright white or grayish yellow abdominal dorsum, with lateral wide, black stripes on each side. In both species, a double row of black slash marks occurs on the posterior half of the abdomen; sometimes these are obscured.

Legs are banded with reddish-brown and pale yellow markings, but those of $N$. crucifera have brown femora, whereas $N$. domiciliorum have red femora. In N. crucifera, the second tibia of the male has two rows of clasping macrosetae ( $N$.

domiciliorum has three rows) and the epigynal scape (part of the female genitalia) has two pairs of bulges (versus one pair in N. domiciliorum). Female $N$. crucifera range from 8.5 to $19.7 \mathrm{~mm}$ in length; males from 4.5 to $15 \mathrm{~mm}$ in length. Usually, Florida specimens are in the upper part of the size range, making them one of the largest orb-weaving spiders in the state. Female $N$. domiciliorum range from 7.2 to

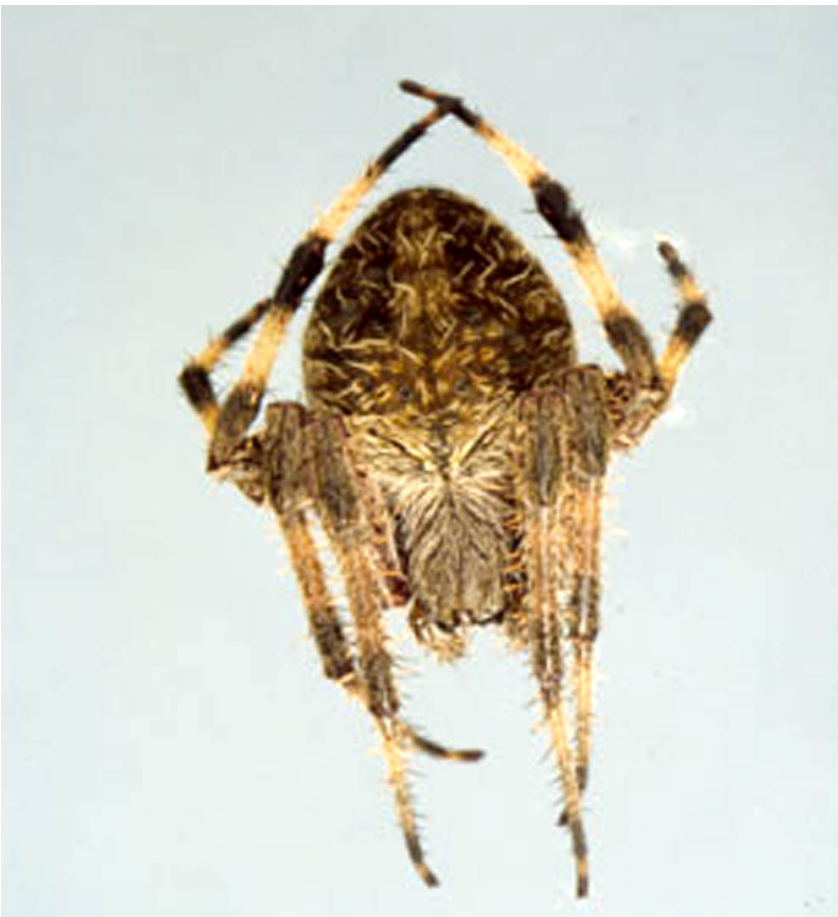

Figure 2. Dorsal view of female Neoscona crucifera (Lucas), an orb weaver. Credits: G.B. Edwards, FDACS-DPI

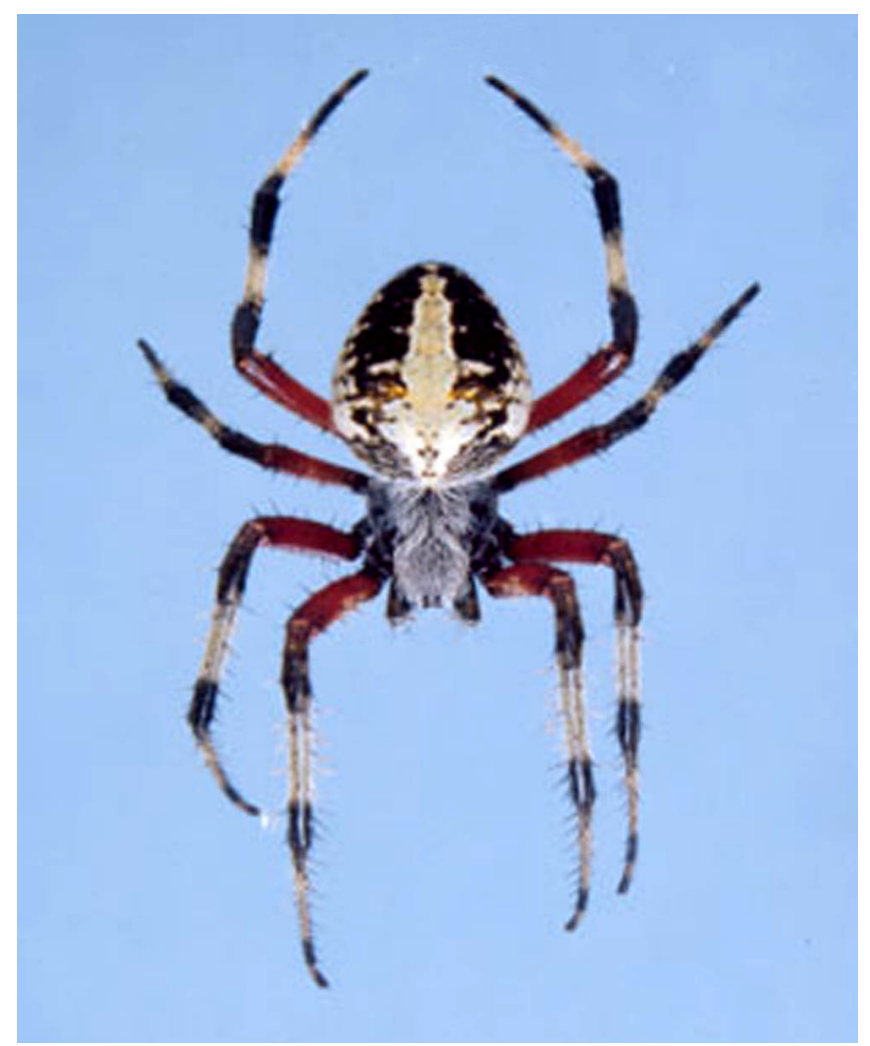

Figure 3. Female Neoscona domiciliorum (Hentz), an orb weaver. Credits: G.B. Edwards, FDACS-DPI 
$16.2 \mathrm{~mm}$ in length; males from 8.0 to $9.0 \mathrm{~mm}$ in length. For both species, Florida specimens usually are larger than more northern specimens (Berman and Levi 1971).

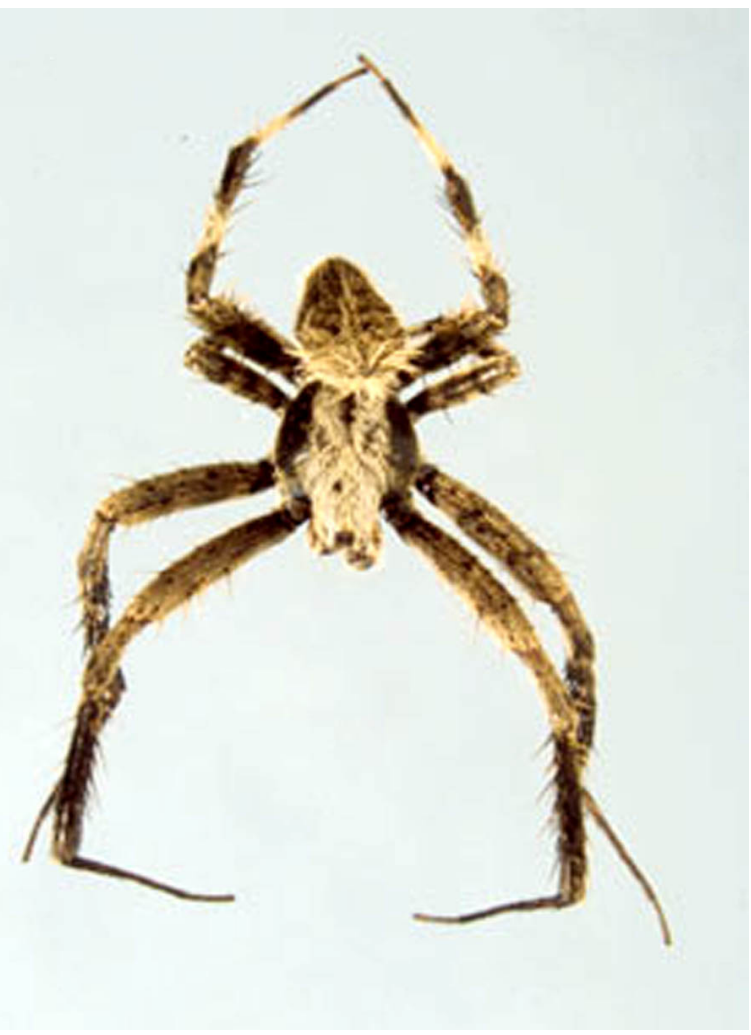

Figure 4. Male Neoscona crucifera (Lucas), an orb weaver. Credits: G.B. Edwards, FDACS-DPI

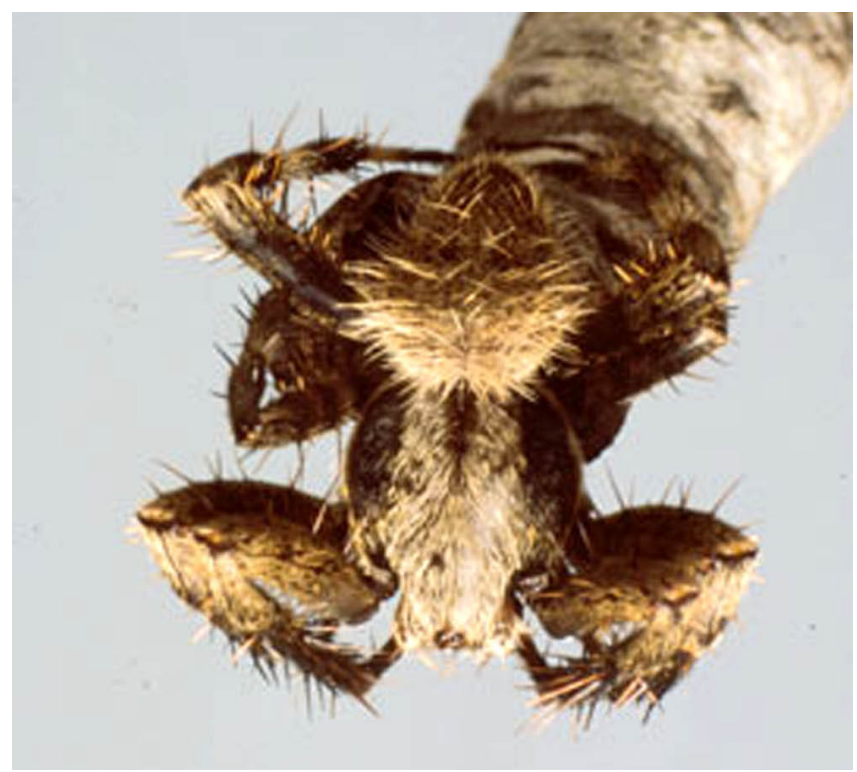

Figure 5. Closeup of male Neoscona crucifera (Lucas), an orb weaver. Credits: G.B. Edwards, FDACS-DPI

\section{Habits and Habitat}

Both species are more common in moist woodland habitats than in drier woods, and seem to prefer those habitats dominated by hardwoods. Juvenile stages usually begin making vertical orbwebs about dusk and take the orbs down shortly after dawn (Kaston 1976). During the day, each spider stays in a retreat made of leaves curled together and tied with silk, located at the attachment of an upper frame thread; frame threads are sometimes left in place. Adult females often leave their webs up and hunt during the day. This may be due to their need for additional food for developing eggs along with a decrease of nocturnal prey in the cooler fall nights.

The orb part of the web of $N$. crucifera may be nearly 2 feet $(60 \mathrm{~cm})$ in diameter (Kaston1976); that of $N$. domiciliorum usually is somewhat smaller. The eggsac of $N$. crucifera consists of fluffy yellow threads in a rolled leaf over a lenticular or spherical egg mass 5-12 $\mathrm{mm}$ in diameter, which may contain up to 1,000 eggs. Juveniles are frequently preyed upon by mud daubers, especially Trypargilum politum (Say) (Hymenoptera: Sphecidae) (Kaston 1948).

\section{Survey and Detection}

Both species of orb weavers are often found on or near buildings. The human occupants may not even be aware of the spiders' presence unless they walk outside after dark and see the web in a lighted area or walk into the web in the dark. Often, the edge of an eave is used as an upper support, with the bottom frame lines attached to a shrub or the ground. A simple silken retreat under the eave may serve as a diurnal shelter. Specimens may be seen in open woodlands by observing webs strung between trees in late fall, or earlier in the year by finding webs at night with a headlight.

\section{Selected References}

Berman JD, Levi HW. 1971. The orb weaver genus Neoscona in North America (Araneae: Araneidae). Bulletin of the Museum of Comparative Zoology 141: 465-500. 
Grasshoff M. 1986. Die Radnetzspinnen-Gattung

Neoscona in Afrika (Arachnida: Araneae). Zool.

Wetensch. 250: 1-123.

Kaston BJ. 1948. Spiders of Connecticut.

Bulletin of the Connecticut State Geological and

Natural History Survey 70: 1-874.

Kaston BJ. 1976. Supplement to the Spiders of Connecticut. Journal of Arachnology 4: 1-72.

Walckenaer CA. 1841. Histoire Naturelle des Insects Apteres. Tome II. Paris. 549 p. 